DOI https://doi.org/10.30525/978-9934-26-073-5-1-32

\title{
НАТУРАЛІЗМ В НОВЕЛІ «НА ДНІ» І. ФРАНКА ЯК ВІДДЗЕРКАЛЕННЯ ДІЙСНОСТІ
}

\author{
Колесник А. В. \\ кандидат філологічних наук, дочент, \\ завідувач кафедри українознавства та іноземних мов \\ Дніпропетровського державного університету внутрішніх справ \\ м. Дніпро, Украӥна
}

Творчість українського письменника Івана Франка вже тривалий час знаходиться в полі уваги науковців. Проте малодослідженим у ній залишається натуралізм зображення євреїв, як головний чинник, що дозволив письменникові показати недоліки суспільства Галичини.

Натуралізм у творчості Івана Франка досліджували такі науковці, як Р. Голод [2], Т. Гундорова [3], М. Ткачук [5], Н. Венгринович [1], Н. Косило [4]. Праці згаданих науковців присвячені як натуралізму у творчому доробку І. Франка, так і конкретним його виявам в окремих творах письменника 3 увагою до міжнародного контексту. Водночас натуралізм як літературно-стильовий напрям, завдяки якому виявилися характерні ознаки зображення євреїв, не досліджувався.

Натуралізм виявився у творах I. Франка при зображенні євреїв найбільше у ранній період. Знаходимо його ознаки у таких творах, як «На дні», «Місія», «Івась Новітний. Повість із тюремного життя», «Домашній промисл», «Гава», «Іригація» та інші. Згадані твори можна розділити на 2 групи - твори раннього періоду й твори більш пізнього часу, написані I. Франком у результаті осмислення історичної ситуації того часу. На думку науковців, Іван Франко у своїй творчості раннього періоду (1980-1990 рр.) свідомо дотримувався програмових вимог натуралізму, використовуючи засоби натуралізму для привернення уваги до необхідності зміни суспільства [2].

У цьому контексті викликає увагу новела «На дні», в якій зафіксовано перебування героя Андрія Темери у в'язниці з подальшим його трагічним завершенням - смертю парубка в результаті умисного вбивства душевнохворим Бовдуром.

Оповідання «На дні» написано I. Франком у час його перебування у в'язниці в Коломиї у 1880 р. Складні умови ув'язнення віддзеркалились на пошуку способів передавання важкого психологічного стану та нелюдських умов, в яких опинився письменник. 
У творі викриваються усі жахіття тюремного середовища, перебування людини у важких, нелюдських умовах тюремного ув'язнення, в оточенні злочинців, чим створюється ефект «дна суспільства» [6, с. 493]. Читача змушує замислитись над тим, що відбувається в суспільстві, життєподібність зображення в новелі, при якій в усіх деталях показано умови тюремної камери, передано страшний психологічний стан кожного в’язня, відтворено безвихідь ситуації.

Отож, у новелі представлено долю та важку ситуацію ще вісьмох ув'язнених, з-поміж яких були і працівники з Борислава, які виявилися за гратами так само несправедливо, перебуваючи в нелюдських умовах. Водночас письменник намагається показати обличчя кожного в’язня, позитивні риси характеру усіх жертв нелюдського режиму.

Вже на початку оповідання письменник знайомить читача 3 кожним в'язнем та контрастно представляє соціальні умови та обставини, що спровокували ув'язнення. Поміж персонажів - два євреї: старий бориславський працівник та молодий хлопець, який є міським злодієм. Другорядність персонажів підкреслює відсутність у них імен, через що вони виявляються позбавленими індивідуальності та особистих рис.

Зображення старого єврея має натуралістичний характер 3 фактографічним відтворенням подій. Зокрема, при зображенні моменту сну персонажа письменник вдається до детального опису умов, за яких лежав старий єврей: як саме, з яким обличчям, як були складені його руки тощо. Звернемо увагу на опис моменту сну і на те, що таким чином автор відтворює важкі соціальні умови, в яких доводилося жити цій людині: «Його голова, коротко обстрижена, спочивала, важко звішена, на мокрій плиті, а на довгій тонкій шиї понадувалися жили, мов понатягяне мотуззя» [6, с. 115]. Отож, копіювання моменту сну, ніби з життя, дає уявлення читачеві про використання цією людиною будь-якого елементу часу для відновлення своїх сил, що узагальнює у свідомості читача уявлення про надмірну перевтому чоловіка. Фактографічний опис, здійснений таким чином, надає найбільшого значення соціальному станові людини, пояснюючи його життєві обставини важкими умовами, що призвели до цього. Усі ці зовнішні риси свідчать про важке життя і постійну роботу, нестачу їі та піклування, що й стало причиною складного стану персонажа.

Опис старого єврея перемежовується згадками про те, що він зріс в оточенні українців, важко працював, як і наші люди, й бідував так само, як й українці. У старого - добре серце, що не дозволяло йому опускатися до жалощів перед іншими, скаржитися на важкі умови життя, але давало йому можливість співпереживати й допомагати іншим. I лише зовнішній 
вигляд 3 пейсами, бородою і бекешею - залишав його «іншим», відмінним від решти населення.

Молодий єврей також є жертвою обставин і перш за все - системи, за рішенням якої він перебуває у камері вже близько двох тижнів і на допит не викликався взагалі. Характеристика персонажа підсилюється порівнянням із собакою. Це відбувається під час сну хлопця і наштовхує читача на думку про його нужденне життя, про вміння пристосовуватися до обставин так, як це роблять тварини. Звернемо увагу на те, що в обох персонажів зафіксована увага на моменті сну з ретельним фіксуванням подробиць, зокрема стану одягу персонажів, що знов повертає читача до соціальної дійсності і пояснює неможливість задовольнити власні потреби персонажів.

Крім того, читача дивує поведінка персонажів, зокрема молодого єврея та Бовдура, ще одного в'язня, який перебуває у камері більше ніж півроку. Об'єктом уваги стає бажання обох персонажів з'їсти шматок хліба, що переростає у криваву бійку. I звичайно, натуралізм стає в нагоді, адже кривава бійка неможлива без відтворення усіх найдрібніших подробиць. Хліб набуває символічного акценту під час бійки, зокрема у той момент, коли кров з носа юнака полилася на хліб. У цьому моменті поєднано несумісні з погляду звичайної людини елементи (хліб і кров), що створюють несподіване враження у читача та закликає до висновку залишатися людиною за будь-яких умов.

Отже, ми побачили у новелі «На дні» увесь набір натуралістичних засобів і прийомів, які дозволили письменникові показати складність соціального життя персонажів. Такі натуралістичні складові, як фактографічне зображення сну персонажів, використання контрастних елементів, об'єктивне відтворення зображуваних подій - створюють основу натуралістичного зображення новели.

Подальші дослідження натуралізму у творчості I. Франка дозволять скласти загальну картину об’єктивної дійсності.

\section{Література:}

1. Венгринович Н. Р. Зооморфна образність у натуралістичній прозі Івана Франка та Френка Норріса. Науковий вісник Міжнародного гуманітарного університету. Серія: Філологія, 2017. Одеса. № 27. Том 1. C. 112-115.

2. Голод Р. Натуралізм. Дивослово. 2012. № 4. С. 50-56.

3. Гундорова Т. Франко не Каменяр. Франко і Каменяр. К.: Критика, 2006. $352 \mathrm{c}$. 
4. Косило Н. В. Типологічні особливості українського та англійського натуралізму в порівняльному аспекті. ВІСНИК Житомирського державного університету імені Івана Франка. 2004, с. 135-138.

5. Ткачук М. П. Жанрова структура прози Івана Франка (бориславський цикл та романи 3 життя інтелігенції). Монографічне дослідження. Тернопіль, 2003. 384 с.

6. Франко І. Зібрання творів: у 50 т. К.: Наукова думка, 1976 - 1986. Т. 15: Повісті ті оповідання (1978 - 1982). 511 с.

DOI https://doi.org/10.30525/978-9934-26-073-5-1-33

\title{
ЦИКЛІЧНІСТЬ ЧАСУ ЯК ОСНОВОПОЛОЖНА КАТЕГОРІЯ ЗБІРКИ Б. ТОМЕНЧУКА «СЕЗОН НЕНАПИСАНИХ ВІРШІВ»
}

\author{
Міняйло С. А. \\ учитель української мови та літератури \\ Харківського ліцею № 141 \\ м. Харків, Україна
}

Поетична збірка «Сезон ненаписаних віршів» Богдана Томенчука $\epsilon$ четвертою у творчому доробку письменника. Проте, на жаль, на сьогодні немає грунтовних досліджень поезій цієї збірки митця, що й зумовлює актуальність нашої розвідки.

Циклічний час - одна 3 форм конкретизації художнього часу. Так, збірка «Сезон ненаписаних віршів» характеризується, перш за все, циклічністю, яка має два аспекти вияву: зовнішній, визначений об'єктивно-темпоральною фіксацією часового циклу; внутрішній, зумовлений психологічним фактором - індивідуально-суб'єктивним сприйняттям, відчуттям невпинного «колообігу» часу [1, с. 224]. I внутрішня, і зовнішня форми фіксації часоплину моделюють образи річного та добового циклів. Одним 3 найкращих проявів циклічного часу стає природній календар, що підтверджуються прикладами 3 творчості безлічі письменників, які торкалися цієї теми у своїх текстах. Особливою увагою користувалися пейзажні мотиви, у яких в найбільшій мірі зберігається єдність національної поетичної свідомості.

Перебіг часу у внутрішньому «я» ліричного героя має певні особливості. Якщо восени ми бачимо його таким, що проник у чимало таємниць буття, психіки («Та осінь світилася так горобинно», «Я в очах твоїх дотиком світла намалюю осінній мотив», «В покосі осіннього сіна», 